ZOOLOGIA 32(5): 360-370, October 2015

http://dx.doi.org/10.1590/S1984-46702015000500005

\title{
Evolution of erythrocyte morphology in amphibians (Amphibia: Anura)
}

\author{
Jie Wei ${ }^{1}$, Yan-Yan Li ${ }^{1}$, Li Wei ${ }^{2}$, Guo-Hua Ding ${ }^{2}$, Xiao-Li Fan² \& Zhi-Hua Lin,* \\ 'School of Life and Environmental Sciences, Hangzhou Normal University, Hangzhou, Zhejiang, 310036, China \\ ${ }^{2}$ Institute of Ecology and Biological Resources, College of Ecology, Lishui University, Lishui, Zhejiang 323000, China. \\ "Corresponding author. E-mail: zhlin1015@126.com
}

\begin{abstract}
We compared the morphology of the erythrocytes of five anurans, two toad species - Bufo gargarizans (Cantor, 1842) and Duttaphrynus melanostictus (Schneider, 1799) and three frog species - Fejervarya limnocharis (Gravenhorst, 1829), Microhyla ornata (Duméril \& Bibron, 1841), and Rana zhenhaiensis (Ye, Fei \& Matsui, 1995). We then reconstructed the ancestral state of erythrocyte size (ES) and nuclear size (NS) in amphibians based on a molecular tree. Nine morphological traits of erythrocytes were all significantly different among the five species. The results of principal component analysis showed that the first component ( $49.1 \%$ of variance explained) had a high positive loading for erythrocyte length, nuclear length, NS and ratio of erythrocyte length/erythrocyte width; the second axis (28.5\% of variance explained) mainly represented erythrocyte width and ES. Phylogenetic generalized least squares analysis showed that the relationship between NS and ES was not affected by phylogenetic relationships although there was a significant linear relationship between these two variables. These results suggested that (1) the nine morphological traits of erythrocytes in the five anuran species were species-specific; (2) in amphibians, larger erythrocytes generally had larger nuclei.
\end{abstract}

KEY WORDS. Amphibia; ancestral state reconstruction; erythrocyte size; morphological comparison; nucleus size.

Amphibians have evolved an array of adaptive structures and mechanisms to cope with environmental changes that result from their life histories, which involves a transition from water to land (Foxon 1964, Wojtaszer \& Adamowicz 2003). One of these adaptations is unusually large erythrocytes, compared to other vertebrates (Wojtaszer \& ADAmowicz 2003). Most previous hematological studies on amphibians counted blood cells (Arserim \& Mermer 2008, Baraquet et al. 2013, Dönmez et al. 2009) and measured their dimensions (DAs \& Mahapatra 2012, Ma et al. 2003, Mahapatra et al. 2012). Both intrinsic (e.g., species, sex, age and physiological state, Aтtademo et al. 2014, НотA et al. 2013, Lajmanovicha et al. 2014) and extrinsic factors (e.g., temperature and habitat, LOPEz-OlIvera et al. 2003) can affect blood parameters (e.g., the blood volume, hematocrit value, fragility and $\mathrm{pH}$ value; see Rouf 1969). For example, the number of erythrocytes differ not only among individuals within population and interspecies, but also with body mass, age and sex of individuals (ArikAn et al. 2003, BANERJEe 1988, CHOUBEy et al. 1986, Das \& Mahapatra 2014), habitat conditions (Romanova \& EgorikHina 2006), and season (Samantaray 1985, Wojtaszek et al. 1997). Therefore, investigating blood parameters in amphibians can facilitate evaluations of the physiological and health levels of populations. These in turn may be used as bio-indicators of environmental conditions, since these parameters exhibit significant variability when individuals inhabit unstable environments (BARNI et al. 2007, DiCKINSON et al. 2002).
Despite the fact that haematological profiles have been reported for many amphibians, reconstruction of the evolutionary history of traits of amphibian erythrocytes is rare. Here, we compare the morphology of the erythrocytes of five sympatric anuran species, including two toads - Bufo gargarizans (Cantor, 1842), Duttaphrynus melanostictus (Schneider, 1799) and three frogs - Fejervarya limnocharis (Gravenhorst, 1829), Microhyla ornata (Duméril \& Bibron, 1841), and Rana zhenhaiensis (Ye, Fei \& Matsui, 1995) -, sampled from natural populations in Lishui, Zhejiang Province, China. These results were combined with recently published accounts on erythrocyte traits (erythrocyte size and nucleus sizes) from three Orders (Gymnophiona, Caudata and Anura) of Amphibia to allow reconstruction of ancestral states and to examine their phylogenetic relationships.

\section{MATERIAL AND METHODS}

From June to August, 2013, we captured 10 adults of each of the following species, B. gargarizans, D. melanostictus, F. limnocharis, M. ornata and $R$. zhenhaiensis, from field of Lishui, Zhejiang Province, China $\left(28^{\circ} 27^{\prime} \mathrm{N}, 119^{\circ} 53^{\prime} \mathrm{E}\right)$. Their snout-vent length (SVL) was $57.5 \pm 4.6,52.5 \pm 2.4,39.2 \pm 2.1,28.6 \pm 0.6$ and $41.4 \pm 1.9 \mathrm{~mm}$, respectively. All individuals were transported to the Herpetological Laboratory of the Lishui University (HLLSU), where they were identified and used for 
preparation of blood smears. Vouchers of $B$. gargarizans are under accession numbers HLLSU-2013071001 to HLLSU2013071010; D. melanostictus from HLLSU-2013072001 to HLLSU-2013072010; F. limnocharis from HLLSU-2013073001 to HLLSU-2013073010; M. ornata from HLLSU-2013074001 to HLLSU-2013074010; and R. zhenhaiensis from HLLSU2013075001 to HLLSU-2013075010.

According to the methods of SALAmat et al. (2013), blood smears were obtained by puncturing the heart of each individual. Blood smears were air-dried, fixed in methanol and stained with $10 \%$ Giemsa (diluted 1:10 in PBS, $\mathrm{pH}=6.8$ ) for 15 minutes and washed in running tap water for 2 minutes. Photos of 100 erythrocytes were taken randomly using a camera attached to a microscope. The morphological traits of erythrocytes, including erythrocyte length (EL) and width (EW), nuclear length (NL) and nuclear width (NW), were measured using Image 1.43 software. Subsequently, erythrocyte size (ES) and nuclear sizes $(\mathrm{NS})$ were calculated as $\mathrm{ES}=[(\mathrm{NL} \times \mathrm{NW} \times$ ð)/ $\left.4, \mu^{2}\right]$ and NS $=\left[(\mathrm{NL} \times \mathrm{NW} \times ð) / 4, \mu \mathrm{m}^{2}\right]$, respectively. Erythrocyte and nuclear shape were compared with EL/EW and NL/ NW ratios and nucleocytoplasmic ratio with NS/ES ratio (SAlamat et al. 2013, SEvinç et al. 2004).

Prior to statistics, all variables were tested for normality and homogeneity. We used linear regression, one-way ANOVA, principal components analysis and Tukey's post hoc comparisons to analyze the data. Throughout this paper, values are presented as mean $\pm \mathrm{SE}$, and the significance level is set at $\alpha=$ 0.05. All statistical analyses were performed with the Statistica software (version 6.0 for PC, Tulsa, OK, USA).

The tests detailed previously were carried out using the topology including all collected amphibian species from Gymnophiona, Caudata and Anura. This topology of species was based on proximate phylogenetic correlation assembled from Pyron \& Wiens (2011). We drew the tree and reconstructed the evolutionary history of ES and NS of amphibians by parsimony ancestral states in the program Mesquite 2.75 (MADDISON $\&$ Maddison 2011). Because branch lengths lacked divergence time and genetic distance and any other metric proportional to the expected variance for the evolution of each analyzed trait were unavailable, we arbitrarily set the initial branch length to 1, which is appropriate for a speciation model of evolution (MARTINS \& GARLAND 1991).

We used ordinary least squares (OLS) and phylogenetic general least squares (PGLS) regressions to estimate the slope for all conventional analyses. These two analyses were implemented in R 2.15.3 (R Development Core Team 2013), using the RMS (Harrell 2012) and Caper (Orme et al. 2012) packages. We used PGLS regression to examine the relationship between NS and ES in amphibians. The PGLS analyses incorporate phylogenetic information into generalized linear models. They offer a powerful method for analyzing continuous data, and have been applied to estimate the evolutionary model and the relationships among the traits of interest
(Barros et al. 2011, Warne \& Charnov 2008). In PGLS, the strength and type of the phylogenetic signal in the data matrix can be accounted for by adjusting branch length transformations, which show the degree of phylogenetic correlation in the data. In this study, we used $\lambda$ from a maximum likelihood approach to evaluate the phylogenetic effects ( $\lambda=0$ indicates no phylogenetic effect, and $\lambda=1$ indicates the strongest phylogenetic effect equivalent to that expected under the Brownian motion model). We used the Akaike Information Criterion (AIC) to estimate merits and drawbacks of the models tested. The best model has the lowest AIC. The model with better ût can be determined by a maximum-likelihood ratio test in which twice the difference in the natural log of the maximum likelihoods (LnL) of OLS and PGLS models will be distributed approximately as a $\chi^{2}$ with degrees of freedom equal to the difference in the number of parameters estimated in the two models (Warne \& Charnov 2008).

\section{RESULTS}

\section{Morphological traits of erythrocyte}

The erythrocytes of the five anuran species are oval, and their morphological traits are depicted in Table 1 . The results of One-way ANOVA indicate that the nine variables of erythrocyte morphology were all significantly different among the five species (Table 1). We found that (1) the mean values of EL and ratio of EL/EW and NL/NW were largest in D. melanostictus and smallest in F. limnocharis, the mean value of EW was larger in $B$. gargarizans than in the other species, the mean value of ES was larger in B. gargarizans and D. melanostictus than in the other species; (2) the mean values of NL and NS were largest in $D$. melanostictus and smallest in F. limnocharis and M. ornata, the mean value of NW was largest in $B$. gargarizans and smallest in M. ornata; (3) the mean value of nucleo-cytoplasmic ratio was largest in D. melanostictus and $R$. zhenhaiensis and smallest in $M$. ornata (Table 1). The variable coefficient was significantly different in NW $\left(\mathrm{F}_{4,45}=4.59, \mathrm{p}<0.01\right.$, Fig. 1$)$, but not in other erythrocyte morphological traits among the five species (all p > 0.05). The variable coefficient of NW was significantly larger in D. melanostictus and R. zhenhaiensis than in $B$. gargarizans, with $F$. limnocharis and $M$. ornata in between (Fig. 1).

A principal component analysis resolved two components (eigenvalues $\geqslant 1$ ) from nine variables of erythrocyte morphology, accounting for $77.6 \%$ of the variation in the original data (Table 2 ). The first component $(49.1 \%$ of variance explained) had high positive loading for EL, NL, NS and ratio of EL/EW. The second axis (28.5\% of variance explained) mainly represented EW and ES. Erythrocyte morphology differed significantly among the five anuran species in their scores on the first axis $\left(\mathrm{F}_{4,45}=45.95, \mathrm{p}<0.0001 ; \mathrm{BG}^{\mathrm{b}}, \mathrm{DM}^{\mathrm{a}}, \mathrm{FL}^{\mathrm{c}}, \mathrm{MO}^{\mathrm{c}}, \mathrm{RZ}^{\mathrm{b}}\right.$, Tukey's test; $\mathrm{a}>\mathrm{b}>\mathrm{c})$ and the second axis $\left(\mathrm{F}_{4,45}=7.38, \mathrm{p}<\right.$ 0.001; $\mathrm{BG}^{\mathrm{a}}, \mathrm{DM}^{\mathrm{b}}, \mathrm{FL}^{\mathrm{b}}, \mathrm{MO}^{\mathrm{b}}, \mathrm{RZ}^{\mathrm{b}}$, Tukey's test; a > b) (Fig. 2). 
Table 1. Descriptive statistics, expressed as mean \pm SE and range, for morphological traits of erythrocytes in five anuran species in Lishui, China, and results of one-way ANOVA for each variable of erythrocytes with species as the factor.

\begin{tabular}{|c|c|c|c|c|c|c|}
\hline Variables & B. gargarizans & D. melanostictus & F. limnocharis & M. ornata & R. zhenhaiensis & Results of statistical analyses \\
\hline \multirow[t]{2}{*}{ Erythrocyte length $(E L, \mu m)$} & $28.17 \pm 0.46$ & $30.02 \pm 0.90$ & $23.92 \pm 0.22$ & $25.20 \pm 0.22$ & $26.96 \pm 0.37$ & $\mathrm{~F} 4,45=23.02, \mathrm{p}<0.0001$ \\
\hline & $25.20-30.27$ & $26.79-36.38$ & $22.56-24.82$ & $24.20-26.19$ & $25.31-29.16$ & $\mathrm{BG}^{\mathrm{ab}}, \mathrm{DM}^{\mathrm{a}}, \mathrm{FL}^{\mathrm{d}}, \mathrm{MO}^{\mathrm{cd}}, \mathrm{RZ}^{\mathrm{bc}}$ \\
\hline \multirow[t]{2}{*}{ Erythrocyte width $(\mathrm{EW}, \mu \mathrm{m})$} & $20.18 \pm 0.50$ & $18.30 \pm 0.48$ & $17.71 \pm 0.28$ & $18.06 \pm 0.21$ & $18.02 \pm 0.22$ & $F 4,45=7.50, p<0.001$ \\
\hline & $18.30-22.28$ & $15.40-21.16$ & $16.65-19.70$ & $17.40-19.37$ & $17.34-19.61$ & $\mathrm{BG}^{\mathrm{a}}, \mathrm{DM}^{\mathrm{b}}, \mathrm{FL}^{\mathrm{b}}, \mathrm{MO}^{\mathrm{b}}, \mathrm{RZ}^{\mathrm{b}}$ \\
\hline \multirow[t]{2}{*}{ Ratio of EL/EW } & $1.41 \pm 0.03$ & $1.66 \pm 0.05$ & $1.37 \pm 0.03$ & $1.40 \pm 0.02$ & $1.51 \pm 0.04$ & $\mathrm{~F} 4,45=13.23, \mathrm{p}<0.0001$ \\
\hline & $1.26-1.56$ & $1.53-1.96$ & $1.25-1.50$ & $1.31-1.50$ & $1.35-1.70$ & $\mathrm{BG}^{\mathrm{bc}}, \mathrm{DM}^{\mathrm{a}}, \mathrm{FL}^{\mathrm{c}}, \mathrm{MO}^{\mathrm{bc}}, \mathrm{RZ}^{\mathrm{b}}$ \\
\hline \multirow[t]{2}{*}{ Erythrocyte size $\left(E S, \mu m^{2}\right)$} & $447.56 \pm 14.87$ & $433.97 \pm 21.79$ & $333.18 \pm 6.70$ & $358.10 \pm 5.99$ & $382.29 \pm 4.24$ & $F 4,45=15.01, p<0.0001$ \\
\hline & $363.21-516.81$ & $338.67-560.78$ & $305.69-379.34$ & $333.67-387.55$ & $363.56-404.21$ & $\mathrm{BG}^{\mathrm{a}}, \mathrm{DM}^{\mathrm{a}}, \mathrm{FL}^{\mathrm{b}}, \mathrm{MO}^{\mathrm{b}}, \mathrm{RZ}^{\mathrm{b}}$ \\
\hline \multirow[t]{2}{*}{ Nucleus length $(\mathrm{NL}, \mu \mathrm{m})$} & $10.49 \pm 0.28$ & $12.54 \pm 0.32$ & $9.20 \pm 0.15$ & $9.57 \pm 0.15$ & $11.32 \pm 0.20$ & $\mathrm{~F} 4,45=34.31, \mathrm{p}<0.0001$ \\
\hline & $8.70-11.71$ & $11.00-14.74$ & $8.62-9.89$ & $8.90-10.38$ & $10.28-12.47$ & $\mathrm{BG}^{\mathrm{b}}, \mathrm{DM}^{\mathrm{a}}, \mathrm{FL}^{\mathrm{c}}, \mathrm{MO}^{\mathrm{c}}, \mathrm{RZ}^{\mathrm{b}}$ \\
\hline \multirow[t]{2}{*}{ Nucleus width $(\mathrm{NW}, \mu \mathrm{m})$} & $6.46 \pm 0.19$ & $6.30 \pm 0.16$ & $5.88 \pm 0.112$ & $5.36 \pm 0.09$ & $6.18 \pm 0.12$ & $\mathrm{~F} 4,45=9.67, \mathrm{p}<0.0001$ \\
\hline & $5.90-7.92$ & $5.67-7.50$ & $5.36-6.51$ & $4.89-5.74$ & $5.71-6.82$ & $\mathrm{BG}^{\mathrm{a}}, \mathrm{DM}^{\mathrm{ab}}, \mathrm{FL}^{\mathrm{bc}}, \mathrm{MO}^{\mathrm{c}}, \mathrm{RZ}^{\mathrm{ab}}$ \\
\hline \multirow[t]{2}{*}{ Ratio of NL/NW } & $1.65 \pm 0.04$ & $2.04 \pm 0.05$ & $1.60 \pm 0.03$ & $1.82 \pm 0.04$ & $1.88 \pm 0.05$ & $F 4,45=16.07, p<0.0001$ \\
\hline & $1.44-1.81$ & $1.80-2.37$ & $1.49-1.85$ & $1.57-2.02$ & $1.53-2.19$ & $\mathrm{BG}^{\mathrm{cd}}, \mathrm{DM}^{\mathrm{a}}, \mathrm{FL}^{\mathrm{d}}, \mathrm{MO}^{\mathrm{bc}}, \mathrm{RZ}^{\mathrm{ab}}$ \\
\hline \multirow[t]{2}{*}{ Nucleus size $\left(\mathrm{NS}, \mu \mathrm{m}^{2}\right)$} & $53.59 \pm 2.74$ & $62.36 \pm 2.70$ & $42.62 \pm 1.32$ & $40.41 \pm 0.94$ & $55.01 \pm 1.24$ & $\mathrm{~F} 4,45=22.02, \mathrm{p}<0.0001$ \\
\hline & $40.34-69.99$ & $50.57-77.05$ & $38.23-50.74$ & $36.33-44.34$ & $49.30-60.38$ & $\mathrm{BG}^{\mathrm{b}}, \mathrm{DM}^{\mathrm{a}}, \mathrm{FL}^{\mathrm{c}}, \mathrm{MO}^{\mathrm{c}}, \mathrm{RZ}^{\mathrm{ab}}$ \\
\hline \multirow[t]{2}{*}{ Ratio of NS/ES } & $0.12 \pm 0.01$ & $0.15 \pm 0.01$ & $0.13 \pm 0.01$ & $0.11 \pm 0.00$ & $0.15 \pm 0.00$ & $F 4,45=5.03, p<0.01$ \\
\hline & $0.09-0.15$ & $0.12-0.22$ & $0.11-0.17$ & $0.09-0.13$ & $0.13-0.17$ & $\mathrm{BG}^{\mathrm{ab}}, \mathrm{DM}^{\mathrm{a}}, \mathrm{FL}^{\mathrm{ab}}, \mathrm{MOb}, \mathrm{RZ}^{\mathrm{a}}$ \\
\hline
\end{tabular}

BG: B. gargarizans, DM: D. melanostictus, FL: F. limnocharis, MO: M. ornata, RZ: R. zhenhaiensis. Means with different superscripts differ significantly (Tukey's post hoc test $\alpha=0.05, a>b>c$ ).

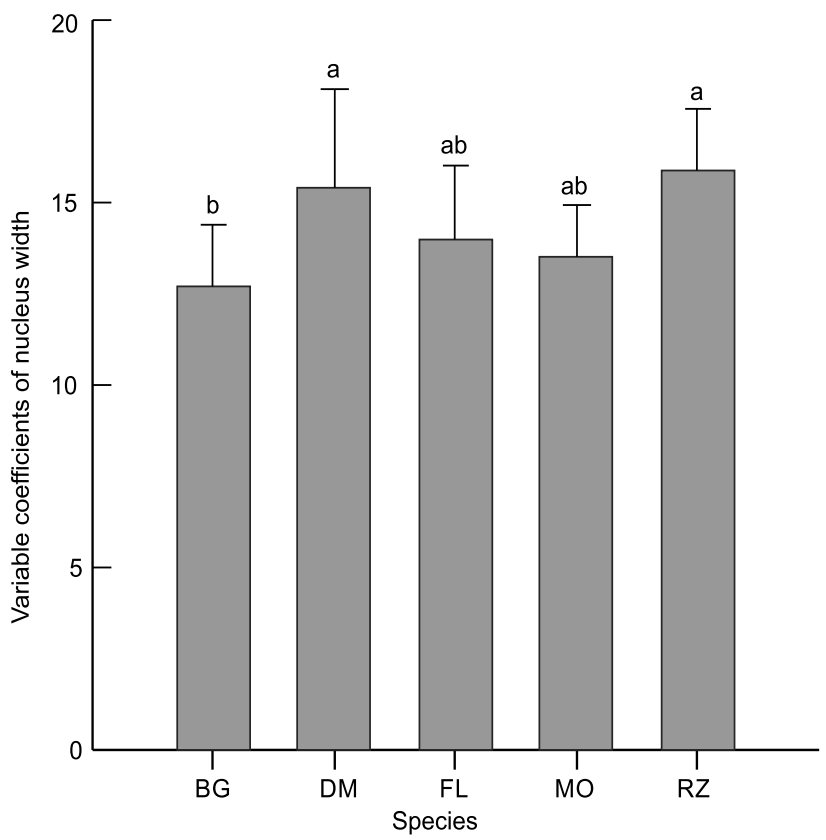

Figure 1 The variable coefficients of nucleus width of five species. BG: B. gargarizans, DM: D. melanostictus, FL: F. Limnocharis, MO: M. Ornata, RZ: R. zhenhaiensis. Different superscripts indicate significant difference (Tukey's post hoc test, $\alpha=0.05, a>b$ ).

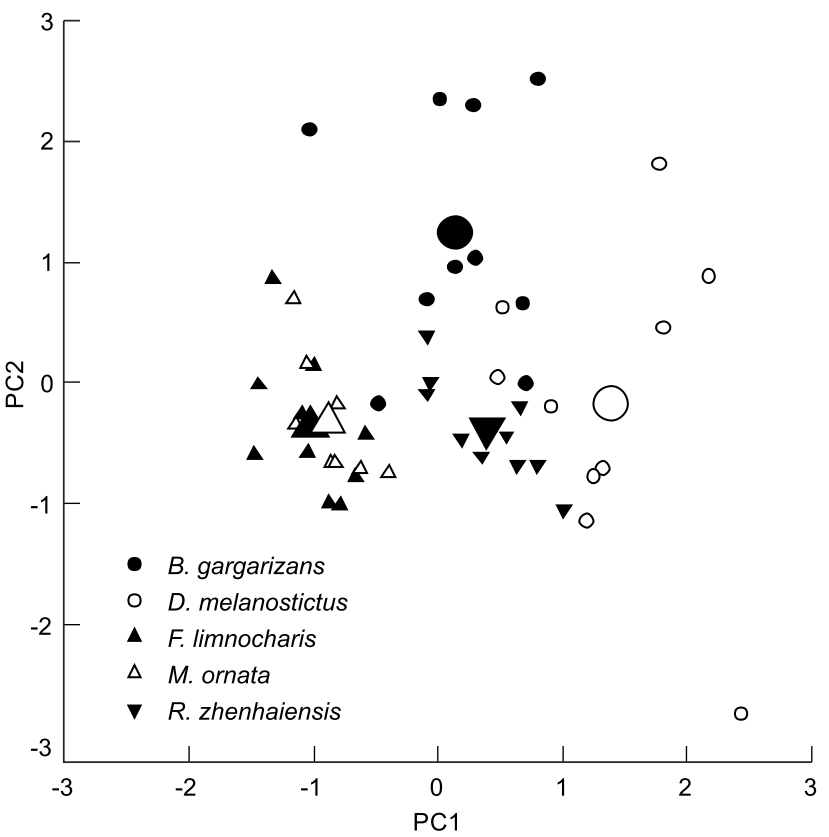

Figure 2 Positions of five anuran species in the space defined by the first two axes of a principal component analysis based on nine variables of erythrocyte morphology. Enlarged symbols show the mean values of scores on the two axes. 
Table 2. Loading of the first two axes of a principal component analysis on nine variables of erythrocyte morphology.

\begin{tabular}{lcc}
\hline & \multicolumn{2}{c}{ Factor loading } \\
\cline { 2 - 3 } & PC 1 & PC 2 \\
\hline Erythrocyte length (EL) & $0.789^{*}$ & 0.403 \\
Erythrocyte width (EW) & 0.052 & $0.974^{*}$ \\
Ratio of EL/EW & $0.776^{*}$ & -0.354 \\
Erythrocyte size (ES) & 0.549 & $0.789^{\star}$ \\
Nucleus length (NL) & $0.967^{*}$ & -0.184 \\
Nucleus width (NW) & 0.592 & 0.377 \\
Ratio of NL/NW & 0.632 & -0.490 \\
Nucleus size (NS) & $0.924^{*}$ & 0.059 \\
Ratio of NS/ES & 0.592 & -0.535 \\
Variance explained & $49.1 \%$ & $28.5 \%$ \\
\hline
\end{tabular}

* Variables with the main contribution to each factor.

\section{Variability of erythrocyte morphology in amphibians}

We assembled published data with our own data on ES, NS for amphibians (Appendix 1). Data from 109 species of amphibians show that mean ES ranged from $119.4 \mu \mathrm{m}^{2}$ to $2649{\mu \mathrm{m}^{2}}^{2}(\mathrm{~N}=108)$ and the mean NS ranged from $18.1 \mu \mathrm{m}^{2}$ to $517 \mu \mathrm{m}^{2}(\mathrm{~N}=71)$. Our reconstruction of evolutionary changes in these variables shows strong positive correlations between NS and ES in amphibians (Fig. 3). The ES and the NS were both significantly different among the three orders of Amphibia (Both $\mathrm{p}<0.01$ ). Both traits were greater in Caudata than in Gymnophiona and Anura (Fig. 4). Table 3 summarizes the relationships between NS and ES in amphibians according to OLS and PGLS analyses. Mean NS was positively correlated with mean ES in both the OLS and PGLS model (Fig. 5, Table 3). PGLS analysis showed that phylogenetic relationships did not affect NS and ES $(\lambda=0)$ although there were significant linear relationship between NS and ES (Fig. 5, Table 3).

\section{DISCUSSION}

Hematological parameters vary significantly among amphibian species (Arikan et al. 2010, Baraquet et al. 2013). For example, Olmo \& Morescalch (1975) documented that interspecific variation is significant in the volume of erythrocytes and nuclei of seven Plethodontidae (Amphibia: Urodela) species. In our study, we found species-specificity in nine morphological traits of erythrocytes in the five anuran species. In general, variation in the morphological traits of erythrocytes in toads (B. gargarizans and D. melanostictus) was larger than in frogs (F. limnocharis, M. ornata, and R. zhenhaiensis). Furthermore, GüL et al. (2011) found that the number of erythrocytes is also different in toads and frogs. The mean value of erythrocyte counts was greater in toads (Pseudepidalea viridis and Pelobates syriacus; $\mathrm{n}=850530 / \mu \mathrm{l}$; GüL et al. 2011) than in frogs
(Hyla arborea, Rana dalmatina and Pelophylax ridibundus; $\mathrm{n}=$ 741332/ $\mu$; GüL et al. 2011). The morphological traits of erythrocytes were different between toads and frogs and this difference may be attributed to the following three reasons. First, the different habitats of toads and frogs may affect the variability of erythrocyte morphology (Romanova \& EgorikHina 2006). Toads mainly inhabit terrestrial environments, whereas frogs inhabit semi-aquatic or aquatic environments (GüL et al. 2011). The terrestrial habitat has selected a series of adaptive structures and mechanisms in frogs that have enabled them to function under conditions of changeable humidity and partial oxygen pressure in terrestrial environments (BARAQUET et al. 2013, Foxon 1964, Wojtaszek \& Adamowicz 2003). Second, erythrocyte size may be dependent on the level of metabolism in vertebrates (WOJTASZEK \& ADAMowicz 2003). Through our field investigation, we found that two toad species (B. gargarizans and D. melanostictus) that crawl slowly and have lower metabolic rate consume less energy than the other three species that are agile in their jumping and swimming activity. Therefore, erythrocyte morphology may have evolved to adapt to various levels of activity in vertebrates. Finally, the body size of animals influences erythrocyte size (FrÝdLová et al. 2012). In our study, the means obtained for the snout-vent length of two toad species (B. gargarizans and D. melanostictus) were greater than the means of the other three frog species ( $F$. limnocharis, M. ornata, and $R$. zhenhaiensis); this distinction was consistent with erythrocyte size. This finding is logical from a physiological point of view, since smaller erythrocytes have relatively larger surface areas, and therefore, exchange oxygen more efficiently. It is reasonable to expect that erythrocyte size is adjusted to the actual mass-specific metabolic rate that gradually decreases during ontogenetic growth (Clemente et al. 2009, SмIтн et al. 2008).

The morphological traits of erythrocytes are variable among individuals of a species. Hota et al. (2013) found that the erythrocyte profile of $M$. ornata is variable during the larval and adult periods. The coefficient of variation (CV) indicated that the level of difference varied among individuals in the same species. Our results showed that the mean values of $\mathrm{CV}$ of NW in D. melanostictus and R. Zhenhaiensis were greater than in B. gargarizans (Fig. 1). These differences may be attributed to the different habitats (Ruiz et al. 1983, SALAmat et al. 2013) and/or variable activity levels (AlLANDER \& Fry 2008, SYKES $\&$ KlaphaKe 2008). Moreover, erythrocyte morphology varies with geography in amphibian species. We pooled erythrocyte size data on B. gargarizans from previous studies and our current study, and found that the erythrocyte profile (EL and EW) differed among three populations from different sampling locations (Guo et al. 2002, ZHou et al. 2011). The EL and EW of $B$. gargarizans in Lishui $\left(28^{\circ} 27^{\prime} \mathrm{N}, 119^{\circ} 53^{\prime} \mathrm{E}\right)$ were greater than in Chongqing $\left(29^{\circ} 81^{\prime} \mathrm{N}, 106^{\circ} 39^{\prime} \mathrm{E}\right.$, Guo et al. 2002), which were greater than in Shuicheng $\left(26.58^{\prime} \mathrm{N}, 104^{\circ} 82^{\prime} \mathrm{E}\right.$, Zноu et al. 2011). However, erythrocyte shape (ratio of EL/EW) showed an op- 
Table 3. Regressions of nuclear sizes (NS) on erythrocyte size (ES) in amphibians based on ordinary least squares (OLS) regression and phylogenetic generalized least squares (PGLS) regression. Significant associations between variables are shown in bold.

\begin{tabular}{|c|c|c|c|c|c|c|c|c|c|c|c|}
\hline & Models & $\mathrm{N}$ & Slope & Elevation & $r^{2}$ & In likelihood & AIC & $\lambda$ & $\mathrm{F}$ & $d f$ & $\mathrm{p}$ \\
\hline OLS & NS vs. ES & 70 & $0.183 \pm 0.009$ & $-1.932 \pm 8.638$ & 0.857 & -367.534 & 741.068 & - & 407.44 & 1,68 & $<0.0001$ \\
\hline PGLS & NS vs. ES & 70 & $0.185 \pm 0.009$ & $-2.100 \pm 9.148$ & 0.850 & -371.570 & 751.140 & 0 & 390.9 & 1,68 & $<0.0001$ \\
\hline
\end{tabular}
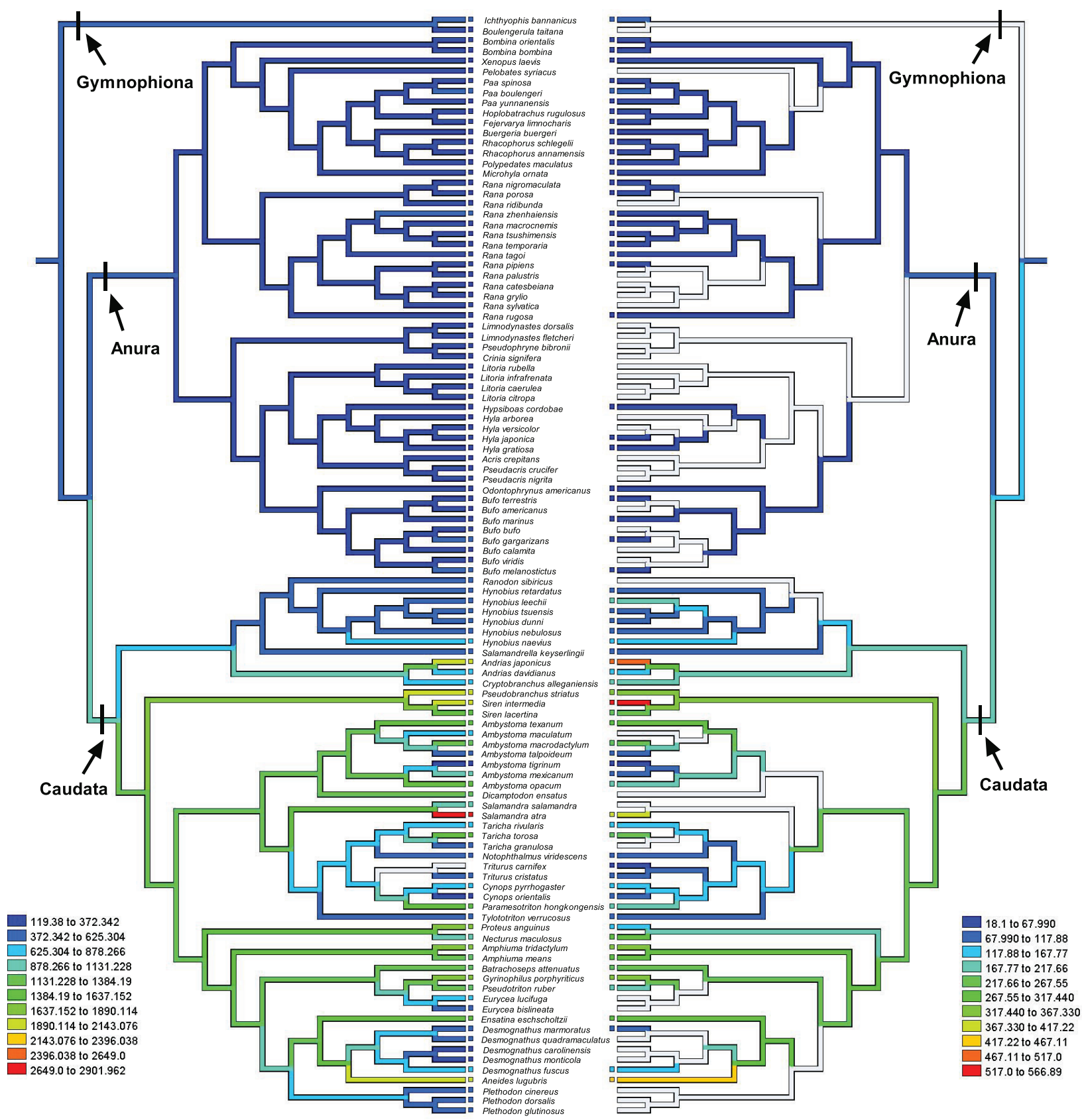

Figure 3 Mirror trees of the evolutionary history reconstructions of erythrocyte size (left side) and nucleus size (right side) of amphibians (blank branch is lack of data), according to phylogenetic hypotheses of PYRON \& WIENS (2011). 

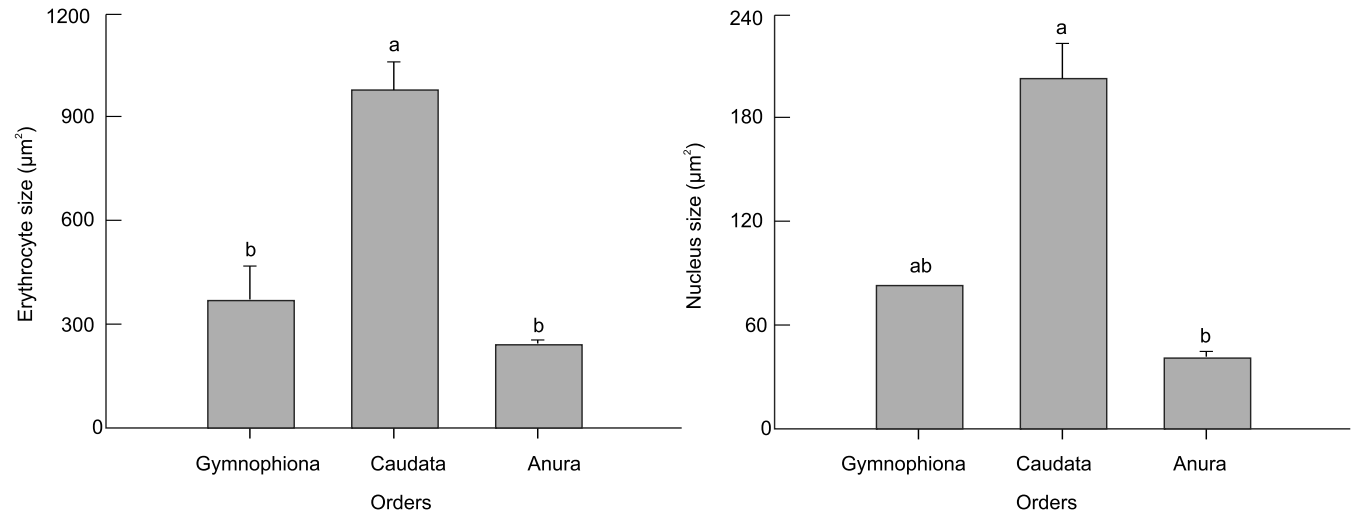

Figure 4 The erythrocyte size and nucleus size of different orders in Amphibia. Different superscripts indicate significant difference (Tukey's post hoc test, $\alpha=0.05, a>b$ ).

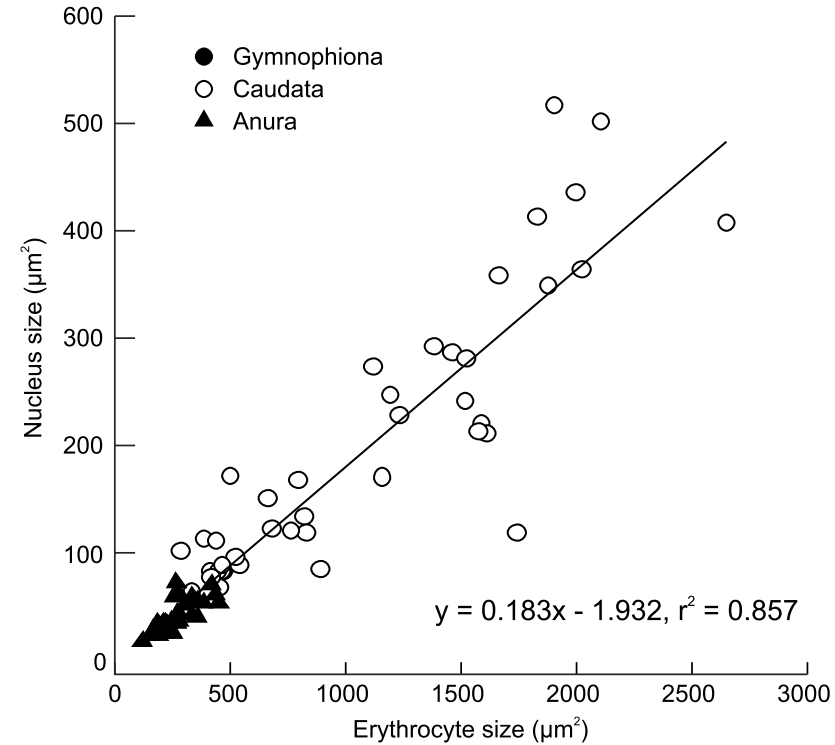

Figure 5 Ordinary least squares (OLS) regression of nucleus size on erythrocyte size in amphibians. Regression equation and coefficient are given in the figure.

posite trend in the three populations (Lishui: 1.41; Chongqing: 1.50; Shuicheng: 1.57). These geographic variations in erythrocyte morphological traits may be associated with differences in latitude, elevation, or environmental and climatic variables in different sampling locations (GoODMAN et al. 2013).Previous studies have found that morphological variation in the erythrocyte traits of amphibians was greater than that in mammals, birds and reptiles (Duellman \& Trueb 1994, Gregory 2001a, Li et al. 1989, SEvinç et al. 2004, Wu et al. 1998). Erythrocyte size in animals is generally negatively correlated with the place where the species appears in an evolutionary tree (whether more basal or more apical, indicating a more recent divergence in time).
Howerver, within Amphibia, species of Gymnophiona have larger erythrocytes than the other species of Caudata and Anura (SZARski \& CZopek 1966). Similar results were found in our study, indicating that the ES and NS in Aunra were the smallest among the three orders, but the ES and NS in Caudata were larger than in Gymnophiona (Fig. 4). This may be the result of insufficient data from a limited number of species (only two species in Gymnophiona) collected from previous reports. Likewise, we still could predict that erythrocyte size in Caudata and Gymnophiona evolved to be larger than that in Anura.

PGLS analysis to recover phylogenetic relationships, showed that these did not affect NS and ES, although there were significant linear relationships between NS and ES (Fig. 5 , Table 3). Similar results were found in 24 species of salamanders, which indicate that the more standard relationships between cell size and NS are similarly significant whether phylogenetically-corrected or not (GREgory 2003). The increase in erythrocyte size may occur adaptively (e.g., to provide more efficient metabolism), and is correlated with an increase in genome size (Gregory 2001b). Mueller et al (2008) demonstrated that positive direct correlations between genome size and NS are significant in the salamander family Plethodontidae. Moreover, the "nucleoskeletal" theory emphasizes the need for a balanced ratio of nuclear and cytoplasmic volumes for the maintenance of cell growth and division, and the key importance of cell size to organismal fitness (GREGORY 2003).

\section{ACKNOWLEDGMENTS}

Our experimental procedures complied with the current laws on animal welfare and research in China. Funding for this work was supported by the National Science Foundation of China (31270443, 31500308 and 31500329) and the Natural Science Foundation of Zhejiang Province (LY13C030004, LQ15C040002 and LQ16C040001). We thank Rui-Yu Yang for helping to collect the animals. 


\section{LITERATURE CITED}

Allander MC, Fry MM (2008) Amphibian haematology. Veterinary Clinics of North America: Exotic Animal Practice 11: 463-480. doi: 10.1016/j.cvex. 2008.03.006

Arikan H, Atatür MK, Tosunolu M (2003) A study on the blood cells of the caucasus frog, Pelodytes caucasicus. Zoology in the Middle East 30: 43-47. doi: 10.1080/09397140.2003.10637986

Arikan H, Alpagut-Keskin N, Çevik IE, Eriomio UC (2010) A study on the blood cells of the fire-bellied toad, Bombina bombina L. (Anura: Bombinatoridae). Animal Biology 60: 61-68. doi: 10.1163/157075610X12610595764174

Arserim SK, Mermer A (2008) Hematology of the Uludað frog, Rana macrocnemis Boulenger, 1885 in Uludað National Park (Bursa, Turkey). Turkish Journal of Fisheries and Aquatic Sciences 25: 39-46.

Atatür MK, ArÝ́kan H, ÇeviK IE (1999) Erythrocyte sizes of some anurans from Turkey. Turkey Journal of Zoology 23: 111-114.

Attademo AM, Peltzer PM, Lajmanovich RC, Cabagna-Zenklusen MC, Junges CM, BAsso A (2014) Biological endpoints, enzyme activities, and blood cell parameters in two anuran tadpole species in rice agroecosystems of mid-eastern Argentina. Environmental Monitoring and Assessment 186: 635-649. doi: 10.1007/s10661-013-3404-z

BANERJeE V (1988) Erythrocyte related blood parameters in Bufo melanostictus with reference to sex and body weight. Environment Ecology Kalyani 6: 802-806.

Baraquet M, Grenat PR, Salas NE, Martino AL (2013) Intraspecific variation in erythrocyte sizes among populations of Hypsiboas cordobae (Anura: Hylidae). Acta Herpetologica 8: 93-97. doi: 10.13128/Acta_Herpetol-12954

Barni S, Boncompagni E, Grosso A, Bertone V, Freitas i, Fasola M, Fenoglio C (2007) Evaluation of Rana snk esculenta blood cell response to chemical stressors in the environment during the larval and adult phases. Aquatic Toxicology 81: 45-54. doi: 10.1016/j.aquatox.2006.10.012

Barros FC, Herrel A, Kohlsdorf T (2011) Head shape evolution in Gymnophthalmidae: does habitat use constrain the evolution of cranial design in fossorial lizards? Journal of Evolutionary Biology 24: 2423-2433. doi: 10.1111/j.14209101.2011.02372.x

Choubey BG, Shankar A, Choubey BJ (1986) Haematological investigation of Himalayan toad Bufo melanostictus Schneider in relation to sex and size. Biological Bulletin of India 8: 106-114.

Clemente CJ, Withers PC, Thompson GG (2009) Meta-bolic rate and endurance capacity in Australian vara-nid lizards (Squamata: Varanidae: Varanus). Bio-logical Journal of Linnean Society 97: 664-676. doi: 10.1111/j.1095-8312.2009.01207.x

Coppo JA, Mussart NB, Fioranelli SA (2005) Blood and urine physiological values in farm-cultured Rana catesbeiana (Anura: Ranidae) in Argentina. Revista de Biologia 53: 545-559.

Das M, Mahapatra PK (2012) Blood cell profiles of the tadpoles of the Dubois's tree frog, Polypedates teraiensis Dubois, 1986
(Anura: Rhacophoridae). The Scientific World Journal 2012: 701746. doi: 10.1100/2012/701746

Das M, Mahapatra PK (2014) Hematology of wild caught Dubois's tree frog Polypedates teraiensis, Dubois, 1986 (Anura: Rhacophoridae). The Scientific World Journal 2014: 491415. doi: 10.1155/2014/491415

Dickinson VM, Jarchow JL, Trueblood MH (2002) Hematology and plasma biochemistry reference range values for freeranging desert tortoises in Arizona. Journal of Wildlife Diseases 38: 143-153. doi: 10.7589/0090-3558-38.1.143

Dönmez F, TosunoĐlu M, Gül Ç (2009) Hematological values in hermaphrodite, Bufo bufo (Linnaeus, 1758). North-Western Journal of Zoology 5: 97-103.

Duellman We, Trueb L (1994) Biology of amphibians. New York, McGraw Hill Inc.

FoxON GEH (1964) Blood and respiration, p. 151-209. In: Moore JA (Ed.). Physiology of the amphibia. New York, Academic Press, XIII+623p.

Frýdlová P, Hnízdo J, Chylíková L, Šimková O, Cikánová V, Velenský P, Frynta D (2012) Morphological characteristics of blood cells in monitor lizards: is erythrocyte size linked to actual body size? Integrative Zoology 8: 39-45. doi: 10.1111/ j.1749-4877.2012.00295.x

GONIAKOWSKA-WITALIÑSKA L (1978) Ultrastructural and morphometric study of the lung of the European salamander, Salamandr salamandra L. Cell Tissue Research 191: 343-56. doi: 10.1007/ BF00222429

Goodman RM, Echternacht AC, Hall JC, Deng LD, Welch JN (2013) Influence of geography and climate on patterns of cell size and body size in the lizard Anolis carolinensis. Integrative Zoology 8: 184-196. doi: 10.1111/1749-4877.12041

Gregory TR (2001a) The bigger the C-value, the larger the cell: Genome size and red blood cell size in vertebrates. Blood Cell, Molecules, and Diseases 27: 830-843. doi: 10.1006/ bcmd.2001.0457

Gregory TR (2001b) Coincidence, coevolution, or causation? DNA content, cell size, and the C-value enigma. Biological Reviews 76: 65-101. doi: 10.1111/j.1469-185X.2000.tb00059.x

Gregory TR (2003) Variation across amphibian species in the size of the nuclear genome supports a pluralistic, hierarchical approach to the C-value enigma. Biological Journal of the Linnean Society 79: 329-339. doi: 10.1046/j.10958312.2003.00191.x

Grenat PR, Bionda CL, Salas NE, Martino AL (2009) Variation in erythrocyte size between juveniles and adults of Odontophrynus americanus. Amphibia-Reptilia 30: 141-145. doi: 10.1163/ 156853809787392667

Gưl Ç, TosunoĐlu M, ErdoĐan D, Özdamar D (2011) Changes in the blood composition of some anurans. Acta Herpetologica 6: 137-147. doi: 10.13128/Acta_Herpetol-9137

Guo XG, Zhang YG, Wang ZJ, Zhang XF (2002) Study on blood cell of Bufo Gargarizans. Sichan Journal of Zoology 21: 211214. doi: 10.3969/j.issn.1000-7083.2002.04.001 
HARRELL FE (2012) RMS: regression modeling strategies. R package version 3.4-0. http://CRAN.R-project.org/package=rms [Accessed: 15/04/2014]

HarTMAN FA, LessLer MA (1964) Erythrocyte measurements in fishes, amphibian, and reptiles. Biological Bulletin 126: 83-88.

Hota J, Das M, Mahapatra PK (2013) Blood cell profile of the developing tadpoles and adults of the ornate frog, Microhyla ornata (Anura: Microhylidae). International Journal of Zoology 2013: 716183. doi: 10.1155/2013/716183

Hu ZY, Lai YP, Chen WJ (2005) Comparison of Blood Cells of Paa spinosa, Rana rugulosa and Rana nigromaculata. Sichuan Journal of Zoology 24: 5-9.

Lajmanovicha RC, Cabagna-Zenklusen MC, Attademo AM, Junges CM, Peltzer PM, Bassó A, Lorenzatti E (2014) Induction of micronuclei and nuclear abnormalities in tadpoles of the common toad (Rhinella arenarum) treated with the herbicides Liberty ${ }^{\circledR}$ and glufosinate-ammonium. Mutation Research/ Genetic Toxicology and Environmental Mutagenesis 769: 7-12. doi: 10.1016/j.mrgentox.2014.04.009

Li J, Li G, Lou D, Meng S, YaO J (2009) Microscopic Structures of Peripheral Hematocytes of the Caecilian Ichthyophis bannanicus. Chinese Journal of Zoology 44: 102-107.

Li PP, He GX, Zhang YH, WANG ZH (1989) The Hematological observation of Chinese giant salamander (Andrias davidianus). Journal of Shaanxi Normal University (Natural Science Edition) 17: 50-53.

Lopez-Olivera JR, Montane J, Marco I, Silvestre AM, Oler JS, Lavin S (2003) Effect of venipuncture site on hematologic and serum biochemical parameters in marginated tortoise (Testudo marginata). Journal of Wildlife Diseases 39: 830-836. doi: 10.7589/0090-3558-39.4.830

MA DB (2005) Morphological parameter of blood cells in Hynobius leechii Boulenger and Salamandrella keyserlingi. Journal of Harbin University 10: 123-124. doi: 10.3969/ j.issn.1004-5856.2005.10.032

MA DB, Wu WF, Wei H (2003) Morphological parameter of blood ceils in Hynobius leechii Boulenger and Cynops orientalis David. Journal of Harbin University 23: 44-45. doi: 10.3969/j.issn.1004-5856.2005.10.032

Maddison WP, Maddison DR (2011) Mesquite: A modular system for evolutionary analysis. Version 2.75. Available online at: http://mesquiteproject.org [Accessed: 29/03/2014]

Mahapatra BB, Das M, Dutta SK, Mahapatra PK (2012) Hematology of Indian rhacophorid tree frog Polypedates maculatus Gray, 1833 (Anura: Rhacophoridae). Comparative Clinical Pathology 21: 453-460. doi: 10.1007/s00580-010-1118-y

Martins E, Garland T (1991) Phylogenetic analyses of the correlated evolution of continuous characters: A simulation study. Evolution 45: 534-557. doi: 10.2307/2409910

MisIEK L, SZARSKI H (1978) Dimensions of cells in some tissues of six amphibian species. Acta Biologica Cracoviensia 21: 127-132.

Monnickendam MA, Balls M (1973) Amphibian organ culture. Experientia 29: 1-17. doi: 10.1007/BF01913222
Mueller RL, Gregory TR, Gregory SM, Hsieh A, Boore JL (2008) Genome size, cell size, and the evolution of enucleated erythrocytes in attenuate salamanders. Zoology 111: 218230. doi: 10.1016/j.zool.2007.07.010

Olmo O, Morescalchi A (1975) Evolution of the genome and cell sizes in salamanders. Experientia 31: 804-806. doi: 10.1007/BF01938475

Orme D, Freckleton R, Thomas G, Petzoldt T, Fritz S, Isaac N (2012) Comparative analyses of phylogenetics and evolution in R. R package version 0.5. Available online at: http://CRANRprojectorg/ package=caper [Accessed: 15/04/2014]

Pyron RA, Wiens JJ (2011) Large-scale phylogeny of Amphibia including over 2800 species, and a revised classification of extant frogs, salamanders, and caecilians. Molecular Phylogenetics and Evolution 61: 543-583. doi: 10.1016/ j.ympev.2011.06.012

Romanova EB, Egorikhina MN (2006) Changes in hematological parameters of Rana frogs in a transformed urban environment. Russian Journal of Ecology 37: 188-192. doi: 10.1134/ S1067413606030076

Rouf MA (1969) Hemamtology of the leopard frog Rana pipiens. Copeia 4: 682-687. doi: 10.2307/1441793

Ruiz G, Rosenmann M, Veloso A (1983) Respiratory and hematological adaptations to high altitude in Telmatobius frogs from the Chilean Andes. Comparative Biochemistry and Physiology A 76: 109-113. doi: 10.1016/03009629(83)90300-6

Salamat MA, Vaissi S, Fathipour F, Sharifi M, Parto P (2013) Morphological observations on the erythrocyte and erythrocyte size of some Gecko species, Iran. Global Veterinaria 11: 248-251. doi: 10.5829/idosi.gv.2013.11.2.75100

Samantaray K (1985) Studies on hematology of Indian skipper frog, Rana cyanophlyctis Schneider. Comparative Physiology and Ecology 10: 71-74.

Sevinç M, UĐurtap ÝH, Yildirimhan HS (2004) Morphological observations on the erythrocyte and erythrocyte size of some Gecko species, Turkey. Asiatic Herpetological Research 10: 217-223.

Smith JG, Christian K, Green B (2008) Physiological ecology of the mangrove-dwelling varanid Varanus indicus. Physiological and Biochemical Zoology 81: 561-569. doi: 10.1086/590372

Sykes IV, Klaphake E (2008) Reptile hematology. Veterinary Clinics of North America: Exotic Animal Practice 11: 481500. doi: 10.1016/j.cvex.2008.03.005

Szarski H, Czoper G (1966) Erythrocyte diameter in some amphibian and reptiles. Bulletin de l'Académie Polonaise des Sciences 14: 433-437.

WANG LW (1996) Observation on the Morphology of Blook Ceel and Test of Blood of Hynobius Lecchii. Journal of Shenyang Teachers College (Natural Science) 14: 53-57.

Warne RW, Charnov EL (2008) Reproductive allometry and the size-number trade-off for lizards. American Naturalist 172: E80-E98. doi: 10.1086/589880 
Wojtaszek J, Adamowicz A (2003) Haematology of the fire-bellied toad, Bombina bombina L. Comparative Clinical Pathology 12: 129-134.doi: 10.1007/s00580-003-0482-2

Wojtaszek J, Baranowska M, Glubiak M, Dzugaj A (1997) Circulating blood parameters of the water frog, Rana esculenta L. at pre-wintering stage. Zoologica Poloniae 42: $117-126$

Wu XB, Zhang SZ, Wu HL (1998) Morphological parameter of blood cells in 16 reptiles species. Chinese Journal of Zoology 33: 29-321. doi: 10.3969/j.issn.0250-3263.1998.01.009

Ye XF, ZhANG JJ, Yuan L, WANG XL (2012) Hematologic studies on Ranodon sibiricus. Journal of Xinjiang Animal Husbandry 11: 33-36. doi: 10.3969/j.issn.1003-4889.2012.11.017

Zhang QY, Li ZQ, GuI JF (1999) Studies on morphogenesis and cellular interactions of Rana grylio virus in an infected fish cell line. Aquaculture 175: 185-197. doi: 10.1016/S00448486(99)00041-1

Zhou QP, Li S, Huang Q (2010) The observation on the blood cells of Paa yunnanensis by LM. Journal of Northwest Normal University 46: 87-90. doi: 10.3969/j.issn.1001988X.2010.04.021

Zhou QP, Zhou XL, Wei GB (2011) Observation on the Blood Cells of Bufo Gargarizans of Shuicheng by LM. Journal of Henan Normal University 39: 136-137, 158.

Submitted: 19 April 2015

Received in revised form: 1 August 2015

Accepted: 29 August 2015

Editorial responsibility: Carolina Arruda Freire

Appendix 1. Erythrocyte size and erythrocyte nuclei size in Amphibia $\left(\mu \mathrm{m}^{2}\right)$.

\begin{tabular}{|c|c|c|c|}
\hline & Erythrocyte size & Nucleus size & Reference \\
\hline \multicolumn{4}{|l|}{ Gymnophiona } \\
\hline \multicolumn{4}{|l|}{ Caeciliidae } \\
\hline Boulengerula taitana & 270.77 & - & GREGORY (2003) \\
\hline \multicolumn{4}{|l|}{ Ichthyophiidae } \\
\hline Ichthyophis bannanicus & 467.72 & 83.41 & Li et al. (2009) \\
\hline \multicolumn{4}{|l|}{ Caudata } \\
\hline \multicolumn{4}{|l|}{ Ambystomatidae } \\
\hline Ambystoma macrodactylum & 1192.00 & 247.00 & Olmo \& Morescalch (1975) \\
\hline Ambystoma maculatum & 711.42 & - & GreGory (2003) \\
\hline Ambystoma mexicanum & 887.74 & 84.78 & GreGory (2003) \\
\hline Ambystoma opacum & 1611.00 & 212.00 & Olmo \& MoresCalch (1975) \\
\hline Ambystoma talpoideum & 538 & 90.00 & Olmo \& MoresCalch (1975) \\
\hline Ambystoma texanum & 1462.00 & 287.00 & Olmo \& Morescalch (1975) \\
\hline Ambystoma tigrinum & 333.25 & 64.32 & GreGory (2003) \\
\hline \multicolumn{4}{|l|}{ Amphiumidae } \\
\hline Amphiuma means & 1383.48 & 292.00 & MonNickendam \& Balls (1973) \\
\hline Amphiuma tridactylum & 1877.09 & 348.34 & HaRTMAN \& LesSLER (1964) \\
\hline \multicolumn{4}{|l|}{ Cryptobranchidae } \\
\hline Andrias davidianus & 821.92 & 133.52 & Lı et al. (1989) \\
\hline Andrias japonicus & 2105.00 & 502.00 & Olmo \& Morescalch (1975) \\
\hline Cryptobranchus alleganiensis & 791.98 & 168.08 & GreGory (2003) \\
\hline \multicolumn{4}{|l|}{ Dicamptodontidae } \\
\hline Dicamptodon ensatus & 1182.83 & - & GREGoRY (2003) \\
\hline \multicolumn{4}{|l|}{ Hynobiidae } \\
\hline Hynobius dunni & 437.00 & 111.00 & Olmo \& Morescalch (1975) \\
\hline Hynobius leechii & 501.38 & 172.56 & WANG 1996, MA et al. (2003) \\
\hline Hynobius naevius & 681.00 & 123.00 & OLMO \& MoresCALCH (1975) \\
\hline Hynobius nebulosus & 445.79 & 83.32 & GreGory $(2003)$ \\
\hline Hynobius retardatus & 413.00 & 83.00 & Olmo \& Morescalch (1975) \\
\hline Hynobius tsuensis & 464.85 & 84.19 & GreGory (2003) \\
\hline Ranodon sibiricus & 409.98 & & YE et al. (2012) \\
\hline Salamandrella keyserlingii & 386.75 & 113.22 & $\mathrm{MA}(2005)$ \\
\hline
\end{tabular}


Appendix 1. Continued.

\begin{tabular}{|c|c|c|c|}
\hline & Erythrocyte size & Nucleus size & Reference \\
\hline \multicolumn{4}{|l|}{ Plethodontidae } \\
\hline Aneides lugubris & 1995.00 & 435.00 & Olmo \& Morescalch (1975) \\
\hline Batrachoseps attenuatus & 1233.00 & 228.00 & Olmo \& Morescalch (1975) \\
\hline Desmognathus carolinensis & 306.22 & - & GREGoRY (2003) \\
\hline Desmognathus fuscus & 765.00 & 122.00 & Olmo \& Morescalch (1975) \\
\hline Desmognathus marmoratus & 417.00 & 77.00 & Olmo \& Morescalch (1975) \\
\hline Desmognathus monticola & 344.05 & - & GreGory (2003) \\
\hline Desmognathus quadramaculatus & 585.51 & - & GReGory (2003) \\
\hline Ensatina eschscholtzii & 1523.00 & 281.00 & Olmo \& Morescalch (1975) \\
\hline Eurycea bislineata & 445.95 & - & GreGory (2003) \\
\hline Eurycea lucifuga & 628.95 & - & GReGory (2003) \\
\hline Gyrinophilus porphyriticus & 1664.00 & 359.00 & Olmo \& Morescalch (1975) \\
\hline Plethodon cinereus & 431.26 & - & GreGory (2003) \\
\hline Plethodon dorsalis & 440.04 & - & GREGoRy (2003) \\
\hline Plethodon glutinosus & 529.89 & - & GREGoRY (2003) \\
\hline Pseudotriton ruber & 1157.00 & 171.00 & Olmo \& Morescalch (1975) \\
\hline \multicolumn{4}{|l|}{ Proteidae } \\
\hline Necturus maculosus & 1119.55 & 273.13 & HaRTMAN \& LessLer (1964) \\
\hline Proteus anguinus & 1740.56 & 118.63 & GreGory (2003) \\
\hline \multicolumn{4}{|l|}{ Salamandridae } \\
\hline Cynops orientalis & 286.76 & 102.54 & MA et al. (2003) \\
\hline Cynops pyrrhogaster & 660.05 & 150.82 & GreGory (2003) \\
\hline Notophthalmus viridescens & 454.58 & 68.82 & GREGoRy (2003) \\
\hline Paramesotriton hongkongensis & 1575.00 & 213.00 & Olmo \& Morescalch (1975) \\
\hline Salamandra atra & 2649.00 & 407.00 & Olmo \& Morescalch (1975) \\
\hline Salamandra salamandra & 878.89 & - & GoNIAKOWSKA-WITALINSKA (1978) \\
\hline Taricha granulosa & 603.77 & - & GREGoRy (2003) \\
\hline Taricha rvularis & 828.00 & 119.00 & Olmo \& Morescalch (1975) \\
\hline Taricha torosa & 1518.00 & 241.00 & Olmo \& Morescalch (1975) \\
\hline Triturus carnifex & - & 62.49 & GREGoRY (2003) \\
\hline Triturus cristatus & 466.53 & 89.46 & GREGoRY (2003) \\
\hline Tylototriton verrucosus & 524.00 & 97.00 & Olmo \& Morescalch (1975) \\
\hline \multicolumn{4}{|l|}{ Sirenidae } \\
\hline Pseudobranchus striatus & 2021.00 & 364.00 & Olmo \& Morescalch (1975) \\
\hline Siren intermedia & 1902.00 & 517.00 & Olmo \& MoresCalch (1975) \\
\hline Siren lacertina & 1587.05 & 221.44 & GREGoRY (2003) \\
\hline \multicolumn{4}{|l|}{ Anura } \\
\hline \multicolumn{4}{|l|}{ Alytidae } \\
\hline Bombina bombina & 256.67 & 60.14 & Atatür et al. (1999), Wojtaszek \& AdAMowicz (2003) \\
\hline \multicolumn{4}{|l|}{ Bombinatoridae } \\
\hline Bombina bombina & 201.01 & - & MIIIEK \& SZARSKI (1978) \\
\hline Bombina orientalis & 306.31 & 52.22 & GreGory (2003) \\
\hline \multicolumn{4}{|l|}{ Bufonidae } \\
\hline Bufo americanus & 183.59 & - & GreGory (2003) \\
\hline Bufo bufo & 220.25 & - & AтATÜR et al. (1999) \\
\hline Bufo calamita & 201.01 & - & GREGoRy (2003) \\
\hline Bufo gargarizans & 447.56 & 53.59 & Our study \\
\hline Bufo marinus & 192.97 & 31.81 & HaRTMAn \& Lessler (1964) \\
\hline Bufo melanostictus & 433.97 & 62.36 & Our study \\
\hline Bufo terrestris & 153.70 & 23.59 & GREGoRY (2003) \\
\hline Bufo viridis & 178.29 & - & ATATÜR et al. (1999) \\
\hline
\end{tabular}

Continues 
Appendix 1. Continued.

\begin{tabular}{|c|c|c|c|}
\hline & Erythrocyte size & Nucleus size & Reference \\
\hline \multicolumn{4}{|l|}{ Dicroglossidae } \\
\hline Fejervarya limnocharis & 333.18 & 42.63 & Our study \\
\hline Hoplobatrachus rugulosus & 169.25 & 29.37 & Hu et al. (2005) \\
\hline Paa boulengeri & 418.85 & 71.71 & Zноu et al. (2011) \\
\hline Paa spinosa & 188.02 & 35.28 & Hu et al. (2005) \\
\hline Paa yunnanensis & 356.79 & 56.03 & Zноu et al. (2010) \\
\hline Acris crepitans & 330.46 & - & GREGoRy (2003) \\
\hline Hyla arborea & 200.45 & - & ATATÜr et al. (1999) \\
\hline Hyla gratiosa & 213.64 & 26.15 & HARTMAN \& LESSLER (1964) \\
\hline Hyla japonica & 222.17 & 34.85 & GREGoRY (2003) \\
\hline Hyla versicolor & 195.09 & - & GREGORY (2003) \\
\hline Hypsiboas cordobae & 265.40 & 40.86 & BARAQUET et al. (2013) \\
\hline Litoria caerulea & 197.50 & - & GreGory (2003) \\
\hline Litoria infrafrenata & 155.43 & - & S. Young (unpubl. data) \\
\hline Litoria rubella & 144.20 & - & GREGORY (2003) \\
\hline Pseudacris crucifer & 183.59 & - & GreGory (2003) \\
\hline Pseudacris nigrita & 141.37 & - & GREGoRy (2003) \\
\hline \multicolumn{4}{|l|}{ Limnodynastinae } \\
\hline Limnodynastes dorsalis & 184.57 & - & GREGORY (2003) \\
\hline Limnodynastes fletcheri & 138.26 & - & GREGORY (2003) \\
\hline \multicolumn{4}{|l|}{ Microhylidae } \\
\hline Microhyla ornata & 358.10 & 40.41 & Our study \\
\hline \multicolumn{4}{|l|}{ Myobatrachinae } \\
\hline Crinia signifera & 215.24 & - & GREGORY (2003) \\
\hline Pseudophryne bibronii & 230.91 & - & GREGORY (2003) \\
\hline \multicolumn{4}{|l|}{ Odontophrynidae } \\
\hline Pelobates syriacus & 161.36 & - & AтAтÜR et al. (1999) \\
\hline \multicolumn{4}{|l|}{ Pipidae } \\
\hline Xenopus laevis & 119.38 & 18.10 & GREGORY (2003) \\
\hline \multicolumn{4}{|l|}{ Ranidae } \\
\hline Rana catesbeiana & 307.91 & - & Coppo et al. (2005) \\
\hline Rana grylio & 314.84 & - & ZHANG et al. (1999) \\
\hline Rana zhenhaiensis & 382.29 & 55.01 & Our study \\
\hline Rana macrocnemis & 278.31 & 36.45 & ARSERIM \& MERMER (2008) \\
\hline Rana nigromaculata & 275.83 & 63.38 & Hu et al. (2005) \\
\hline Rana palustris & 203.48 & - & GREGORY (2003) \\
\hline Rana pipiens & 206.01 & 35.94 & GREGoRY (2003) \\
\hline Rana porosa & 267.99 & 36.05 & GREGoRy (2003) \\
\hline Rana ridibunda & 276.65 & - & AтAтÜr et al. (1999) \\
\hline Rana rugosa & 336.35 & 60.32 & GREGORY (2003) \\
\hline Rana sylvatica & 330.46 & - & GREGORY (2003) \\
\hline Rana tagoi & 273.24 & 44.77 & GREGoRy (2003) \\
\hline Rana temporaria & 250.00 & 25.76 & GREGORY (2003) \\
\hline Rana tsushimensis & 247.59 & 38.05 & GREGoRY (2003) \\
\hline \multicolumn{4}{|l|}{ Rhacophoridae } \\
\hline Buergeria buergeri & 202.16 & 30.04 & GREGORY (2003) \\
\hline Polypedates maculatus & 176.34 & 32.04 & MAHAPATRA et al. (2012) \\
\hline Rhacophorus annamensis & 199.49 & 31.02 & GREGORY (2003) \\
\hline Rhacophorus schlegelii & 225.63 & 33.55 & GreGory (2003) \\
\hline
\end{tabular}

ZOOLOGIA 32(5): 360-370, October 2015 